\title{
Molecular detection of equine herpes virus-1 in local horses \\ (Equus feruscaballus) and donkeys (Equus asinus) \\ Sadun Ali Al-Ajeeli Karim
}

Department of Microbiology, College of Veterinary Medicine, University of Diyala, Iraq.

E-mail: alajeelikarim@gmail.com

Received: $12 / 12 / 2017$

Accepted: $16 / 1 / 2018$

Publishing: 28/6/2018

\section{Summary}

Equine herpsvirus type1 was classified as a member of the subfamily Alphaherpesvirinae. It was reported to cause respiratory, reproductive and neurologic infection in horses. The reproductive form of the disease induces abortion in pregnant mare, while the neurologic form is associated with paralysis of infected horses. This study was designed for molecular detection of Equine herpsvirus type1 by polymerase chain reaction. Blood buffy coat samples were collected from 25 horses (Equus feruscaballus) and 25 donkeys (Equus asinus) admitted to local private veterinary clinics around Baghdad and Baaquba cities. DNA was extracted from such samples by the use of DNA extraction kit of COLLECTAGENE ${ }^{\mathrm{T}}$. The samples were subjected to conventional PCR test using specific primers for $g B$ gene of equine herepesvirus-1. Forward primer (F) (5' TAACTGAGATCT AACCGAC 3') and reverse primer (R) (CATATATAGCTATCACGTCC 3'). One buffy coat sample from aborted mare and one buffy coat sample from a donkey suffering from acute respiratory clinical signs were inoculated in mice to follow the fate of equine herepesvirus-1in nasal turbinates, cervical lymph nodes and lungs of these mice. The results showed that only 4 samples from horses and 2 samples from donkeys were positive to polymerase chain reaction. Experimentally infected mice did not show any clinical signs but they were positive to polymerase chain reaction, and the virus easily terminated, probably due to low dose of the virus and host specificity. It can be concluded that local horses and donkeys, somewhere have had infected with equine herepesvirus-1, and became latent carriers for the virus. Furthermore, microbiological and epidemiological studies on local Equine herpsvirus type1 and Equine herpsvirus type 4 are recommended.

Keywords: Equine herpesvirus-1, Equus feruscaballus, Equus asinus, Mice, Polymerase chain reaction.

\section{Introduction}

Equine herepesvirus-1 (EHV-1) belongs to Herpesviridae. It was reported by many researchers to cause respiratory, reproductive and neurologic infection in horses (1-3). Generally $E H V-1$ causes mild respiratory infection, but the reproductive and neurologic form of the disease were of special importance, they cause of economic losses in horses when compared to the respiratory form of the disease which is self-limiting (2 and 4). Reproductive form of the disease occurs as abortion associated with high fever in pregnant mares, while the neurologic form was associated with paralysis of infected horses (5 and 6). Many other reports mentioned experimental infection (7) or the natural occurrence of $E H V-1$ infection in donkeys (8 and 9). Some workers mentioned new herpes viruses associated with respiratory (10) and reproductive infections (11) of donkeys. It is well known that herpes viruses cause latency in infected host (1). Latency is a key element of EHV-1 biology as a survival strategy. Persisting within infected horses without clinical signs of disease, virus shedding or cell associated viraemia, $E H V-1$ can be shed and infect susceptible horses after reactivation (2). $E H V-1$ was also known to replicate in lymphoid cells infected in vitro and in vivo during systemic infection. Leukocyteassociated viraemia can be observed that involving infection of leukocytes and lymphoreticular cells. Thus these cells become important reservoirs for persistent viral infection (12 and 13). Mice were used as a potential animal model in experimental infections for this virus by many workers (1416). Experimentally infected mice with $E H V-1$ 
produced clinical signs, like respiratory distress and weight loss (16 and 17).

Diagnosis of viral respiratory infection cannot be done depending on clinical signs as there are many causative agents for such diseases (1 and 4). $E H V-1$ is an enveloped double stranded DNA virus, accordingly many Polymerase chain reaction (PCR) programs were used for the detection of viral genome in samples collected from naturally or experimentally infected animals (18-22). In Iraq, there is no data available on the $E H V-1$ in local horses or donkeys, accordingly the present study aimed to molecular detection of $E H V-1$ from the possible infected horses and donkeys, and explore the fate of $E H V-1$ in experimentally infected mice.

\section{Materials and Methods}

Twenty five draft horses and 25 working donkeys were admitted to private veterinary clinics in the period from July 2015 to June 2016, of both sexes and different ages. Fifteen horses and eleven donkeys were from Baghdad city. Ten horses and fourteen donkeys were from Baaquba city. One mare only aborted a week before admission and one male donkey suffered from acute respiratory signs. The history of all cases was recorded. The laboratory works and mice inoculations were achieved in the laboratory of Veterinary Medicine College/ University of Diyala.

Twenty $\mathrm{ml}$ of blood samples were collected from Jugular vein of each animal and transferred in glass tubes containing EDTA, in order to obtain buffy coat of plasma by cooled centrifugation (Eppendorf 5810R). The buffy coat samples were preserved at $-30^{\circ} \mathrm{C}$ until used. Later, the buffy coat samples were divided equally in to 2 parts: One used for DNA extraction and the other returned to freezer for further studies. DNA was extracted from blood buffy coat samples by the use of DNA extraction kit of COLLECTAGENE ${ }^{\mathrm{T} *}$ and according to manufacturer. The same kit was used to extract the DNA from tissue samples of experimentally infected mice. Fifty five mice BALB/C of different sex and ages were used for inoculation. They were divided into three groups as follow:

Group A, include 22 mice used for inoculation with aborted mare buffy coat sample. Group B, include 22 mice also used for inoculation with male donkey (that suffered from acute respiratory signs) buffy coat sample and Group C, include 11 mice inoculated with sterile normal saline to represent a control group. The control group was kept far from the other groups to avoid transmission of infection.

Hundred $\mu$ l of thawed buffy coat of aborted mare sample were dropped intra-nasally of each mouse of group A. The same was done for group B, except using buffy coat of male donkey. The control group was inoculated with $100 \mu \mathrm{l}$ of sterile normal saline by the same route. Collection and Processing of mouse tissues for PCR: Two mice were killed daily from each group $\mathrm{A}$ and $\mathrm{B}$, while only one mice was used from group C. Killing was started from day one post-inoculation (PI) until 11 days PI. Tissue samples included nasal turbinate, lung, and cervical lymph nodes, were collected and kept in Bijou bottles with sterile transport medium. The collected tissues in particular time from each group were pooled together and homogenized at 1600 rpm, transferred into sterile Eppendorf tube, and kept at $-30^{\circ} \mathrm{C}$ until use. These samples were, thawed at room temperature and used for DNA extraction for PCR as mentioned above. *COLLECTAGEN $^{\mathrm{T}}$ : Takara Bio. Inc., Nojihigashi, 7-4-38, Kusatsu, Shiga 525-0058 Japan.

Amplification by PCR: DNA extracted from tissues and buffy coat were used in this experiment for PCR analysis. $15 \mu \mathrm{l}$ from each DNA sample was mixed with PCR mixture Gene Amp®* in $0.5 \mathrm{ml}$ PCR Eppendorf tube. The mixture was composed of $16 \mu \mathrm{l}$ of nucleotides (dATP, dGTP, dCTP and dTTP), $1 \mu \mathrm{l}$ Taq polymerase $(5 \mathrm{U} / \mu \mathrm{l}), 1 \mu \mathrm{l}$ primer 1 , $1 \mu 1$ primer 2, $10 \mu \mathrm{l}$ PCR buffer (10x), and 56 $\mu 1$ sterile deionized distilled water. Primers were selected from the $E H V-1$ glycoprotein $(g B)$ which had 459 base pairs. The two primers were as: forward (F) (5' TAACTGAGATCTAACCGAC 3') and reverse (R) (CATATATAGCTATCACGTCC $\left.3^{\prime}\right)$. The mixture with DNA sample was processed as $95^{\circ} \mathrm{C}$, denaturation for 5 minutes, followed by a 40 PCR cycles using Eppendorf thermocycler (each cycle was programed as 95 ${ }^{\circ} \mathrm{C}$, denaturation for 1 minute, $55^{\circ} \mathrm{C}$, annealing 
for 1 minute, and $72{ }^{\circ} \mathrm{C}$, extension for 2 minutes. This was followed by one cycle of long extension of $72{ }^{\circ} \mathrm{C}$ for 10 minutes. The cycler was then dropped to $4{ }^{\circ} \mathrm{C}$, and the PCR product was electrophoresed. Electrophoresis of the PCR sample was carried out by the use of $25 \mu \mathrm{l}$ of PCR product loaded in well of $1.5 \%$ agarose in 1 xTBE running buffer $(0.025$ M Tris, $0.192 \mathrm{M}$ glycine, $0.1 \%$ w/v SDS). The gel was run at $90 \mathrm{~V}$ for an indicated period of time using a $0.1 \%$ bromophenol blue as an indicator and bacteriophage $\varnothing \mathrm{X} 174$ DNA molecular weight marker (DNA ladder). Followed electrophoresis, the gel was stained with ethidium bromide $(0.5 \mu \mathrm{g} / \mathrm{ml})$ for 15 minutes, and DNA products visualized by UV illuminator and photographed.

\section{Results and Discussion}

PCR products of blood buffy coat samples showed that only 4 samples from horses and 2 samples from donkeys were positive (Table,1).

Table, 1: Number of samples with positive EHV-1 PCR product.

\begin{tabular}{c|cc|c}
\hline $\begin{array}{c}\text { Animal } \\
\text { species }\end{array}$ & $\begin{array}{c}\text { Number } \\
\text { of samples }\end{array}$ & $\begin{array}{c}\text { PCR } \\
\text { Samples } \\
\text { positive for } \\
\text { EHV-1 }\end{array}$ & $\begin{array}{c}\text { PCR } \\
\text { Samples } \\
\text { negative for } \\
\text { EHV-1 }\end{array}$ \\
\hline Horses & $\mathbf{2 5}$ & $\mathbf{4}$ & $\mathbf{2 1}$ \\
Donkeys & $\mathbf{2 5}$ & $\mathbf{2}$ & $\mathbf{2 3}$ \\
\hline
\end{tabular}

Blotting a graph for electrophoresed known MW DNA fragments of bacteriophage $\varnothing \mathrm{X} 174$ marker $(1353,1078,872,603,310,281,234$ and $194 \mathrm{bp}$ ) in conjunction with the distance of their migration in gels used to determine the MW of PCR product which was $459 \mathrm{bp}$ as mentioned by the manufacturer (Fig. 1). Detection of viral genome in such samples comes in agreement with findings of many workers as it is well known that $E H V-1$ caused latency in infected animals, and the genome hide in the suspected or incorporated with host cell genome of lymph nodes or circulating lymphocytes (1, 4 and 20). Because of some risk factors that included immunosuppression and/or the action of cytokines or hormones, the virus might be re-expressed and caused the infection $(8,12$ and 18$)$.

*GeneAmp®: 850 Lincolin Center Drive, Foster City, CA 94404, USA.

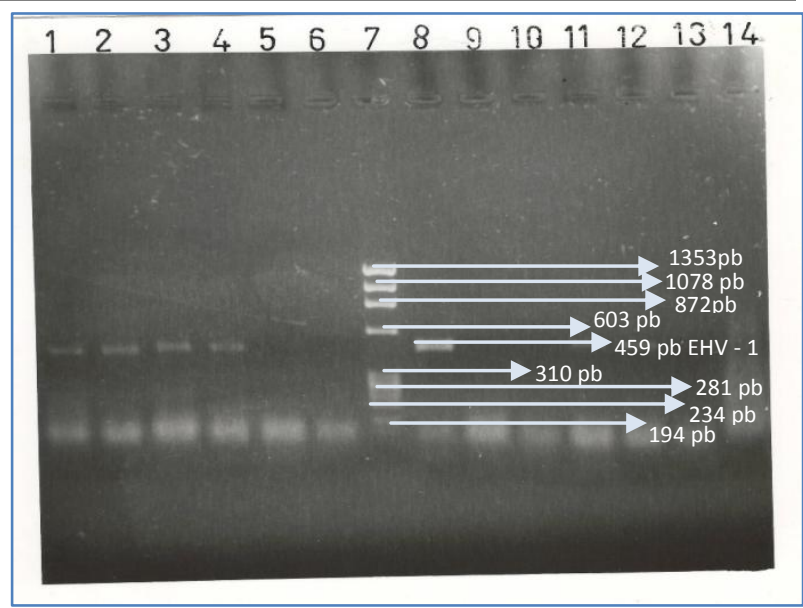

Figure, 1: Amplification of EHV -1 from horses and donkeys samples. Lanes $1-4$ are positive samples from horses. Lanes 5 and 6 are from horse negative samples. Lane 7 is DNA molecular weight marker (bacteriophage $\varnothing$ $x$ 174). Lane 8 is EHV-1 kit marker. Lanes 9, 10, 13 and 14 are from donkey negative buffy coat samples. Lanes 11 and 12 are positive donkey samples. All samples are electrophorised in $1.5 \%$ agarose gel at 90 volts for 2 hours, and stained with ethidium bromide.

Outbreaks in horses or donkeys might be occurred by the close contact of susceptible animals with those infected with $E H V$-1, and through the nasal secretion especially in the respiratory form and contaminated fluid from aborted fetus from infected mares (1 and 4). Few positive samples ( 6 out of 50 samples) of this study might be attributed to the fact that horses and donkeys in this country were not raised in high population. Using of horses and donkeys in few numbers or as individuals reduce the possibility of viral transmission and occurring of outbreaks (4). Furthermore, those animals of present study were mostly stressed as used for hard working to transport goods or equipment. The results of this study pointed clearly that such animals were infected with the virus in the certain past time and in somehow. Donkeys were found to be susceptible to the infection with $E H V$-1. This finding was supported the finding of other worker as they reported that donkeys can be infected with $E H V-1$ (8 and 9).In contrast new virus known as equid herpesvirus-7 has been recently reported to be associated with abortion in Mediterranean miniature (Equus asinus) (11). This might be another virus that can cause abortion in donkeys rather than $E H V$-1. Experimental infection on donkeys and ponies with EHV-1 of horse origin showed that donkeys were refractory to infection in comparison to ponies (7). Another 
study (10) had mentioned two new herpesviruses, asinine herpesvirus 4 (AsHV-4) and $5(A s H V-5)$ were associated with respiratory tract infections and they were closely related. Furthermore, these viruses were grouped in Gammaherpesvirinae, while EHV-1 was grouped in Alphaherpesvirinae. The finding of present study reported that primers for $g B$ gene detected similar sequences to $E H V-1$ in donkeys.

Processing of mouse tissues from experimentally infected mice by blood buffy coat of aborted mare didn't give any PCR product (Fig. 2). Mice inoculated with blood buffy coat of respiratory sick donkey gave a clear band of $459 \mathrm{bp}$ of $E H V-1$ in mice turbinates 1 day PI, and it was cleared by 5 days PI. Lung tissue gave clear PCR band at 3 days PI until 6 days PI. Furthermore, the DNA of $E H V-1$ was detected in lymph nodes of mice at 4 days PI until 6 days PI. No viral DNA was detected at 7 to 11 days PI. Mouse tissues collected from control animals didn't show any DNA PCR product, and they were negative for $E H V-1$ (Table, 2 and Fig. 2).

Table, 2: $E H V$-1 PCR DNA of $g B$ gene product as was detected in days PI of mice tissues inoculated with blood buffy coat from infected donkey.

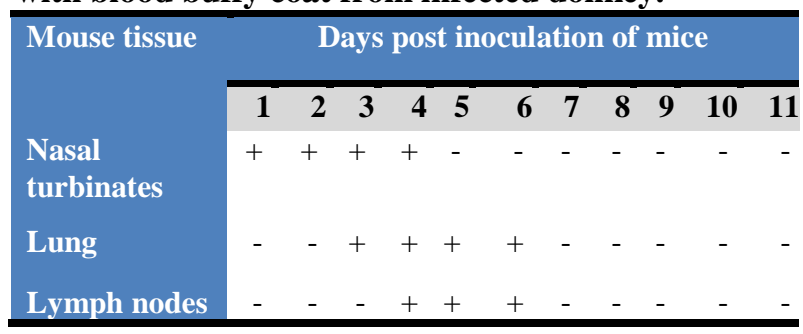

In mice inoculated with male donkey samples, the virus followed the same sequence of antigen fate reported by many authors (1416). This finding might indicate that the infection of such donkey has recently occurred or might be related to reactivation of the virus from past infection. The virus was cleared out from infected mice without clinical signs, and this might attributed to the dose of the virus, as it was reported that clinical signs in infected mice associated with high dose of viruses per inoculum (23). Cell mediated immunity was appeared as the main immune response in clearing or eliminating $E H V-1$ infections (23 and 24). Furthermore, low doses can be cleared out by immune system without clinical signs (25). In the present study, the virus was not isolated, accordingly its infective dose 50 (ID50) was not determined.

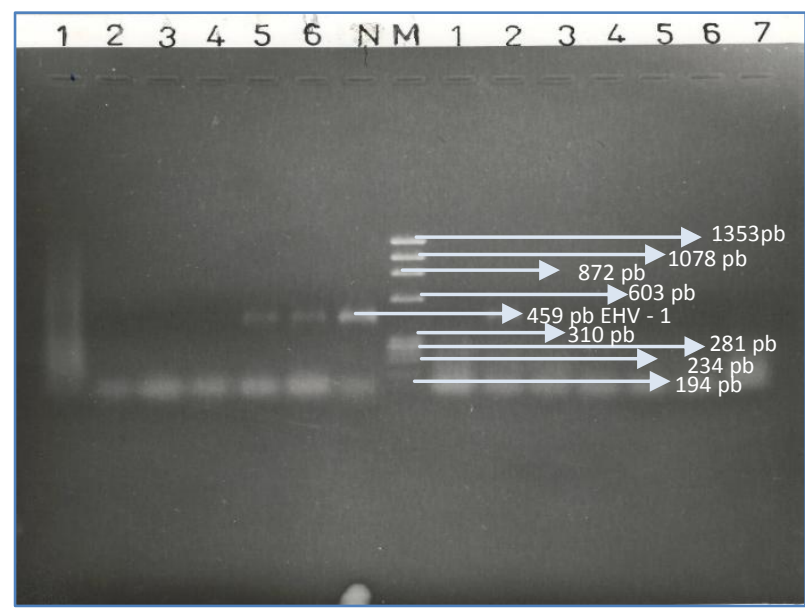

Figure, 2: Amplification of $E H V-1$ from tissue samples of mice. Lanes from left to right are: Lanes 1 to 4 are from mice tissues of negative control. Lanes 5 and 6 are from nasal turbinates and lungs of the infected mice. Lane $\mathbf{N}$ is the positive EHV-1 kit's control. Lane $M$ is the bacteriophage ø174 DNA molecular weight marker, Lane 1 is the lymph node tissue of negative control mice Lane 2 is the lymph node tissue sample form infected mice, Lanes from 3 to 7 are of different tissue samples from infected mice 11 days post infection.

An experimental infection of mice by buffy coat of mare failed to give any signs of infection, and $g B$ gene sequence was not detected by PCR in samples collected from mice. It depends on the fact that infected and aborted mares due to EHV-1 might hold the virus in their blood more than 3 weeks ( 3 and 4). It seemed that the abortion in such a mare was due to some other causes rather than $E H V$ 1. Accordingly, buffy coat sample of aborted mare carried a latent viral genome of $E H V-1$ virus; and the virus might be reactivated due to the stress factor of abortion and in low amount and easily eliminated by the immune system of experimentally infected mice (23 and 25).

Conventional PCR technique was used in this study to detect $E H V-1 g B$ gene in blood buffy coat of horse, and in tissue samples from mice. OIE report, 2017 (4) mentioned that PCR was the most reliable and sensitive technique for diagnostic purposes. PCR also was used by many workers (26 and 27). Some other workers used real time PCR for diagnostic purposes with same abovementioned sensitivity (28 and 29), targeting the $g B$ gene of the $E H V-1$ (30). In conclusion, local horses and donkeys were infected by 
$E H V-1$ previously and carried latently the virus and the virus might be reactivated due to some stress factors. Such animals became carriers of active virus (4 and 18). Presence of latent DNA genome in such animals does not prevent them from the re-infection (4). Another (18) detected EHV-1 and 4 in healthy horses by the use of PCR. Performing of wide epidemiological, serological and molecular biological studies are recommended to point out the spread of herpes virus and/ or viruses in horses and donkeys. In this aspect, the virus needed to be isolated from donkeys and a genetic comparative study may be carried out to find the virus of the study is $E H V-1$ or $A s H V-3$ or others.

\section{References}

1. MacLachlan, N.J. and Dubovi, E.J. (2011). Fenner's Veterinary Virology" $4^{\text {th }}$ Ed. ELSVER Academic Press, London. Pp:179201.

2. Paillot, R.; Case, R.; Ross, J.; Newton, R. and Nugent J. (2008). Equine Herpes Virus -1: Virus: Immunity and Vaccines. Open Vet. Sci., J., 2:68-91.

3. Cruz, F. and Newton, R. (2010). Focus article: Managing an outbreak of Equine Herpes Virus-1. AHI/BEVA/DEPRA Equine Quartery Dis. Surveillance Rep., 6(4):13-17.

4. OIE Terrestrial Manual (2017). Equine Rhinopneuminitis (infection With Equid Herpes Virus-1 and -4). Pp:1-13.

5. Goehring, L.; Van Maanen, C.; Berendson, M.; Cullinane, A.; deGroof, R.J.; Rottier, P.J.M.; Wesselimgh, J.J.C.M. and Oldruitenborgh-Oosterbaan, M.M.S. (2010) Experimental infection with neuropathogenic equid herpesvirus type $1(\mathrm{EHV}-1)$ in adult horses. Vet. J., 186(2):180-187.

6. Pusterla, N.; Wilson, W.D.; Madigan, J.E.; and Ferraro, G.L. (2009). Equine herpesvirus1 myeloencephalopathy: A review of recent developments. Vet. J., 180:279-289.

7. Gupta, A.K.; Rattan, B.; Malik, P.; Kuar, D.; Singh, B.K. and Yadav, M.P. (2000). Experimental Infection of Donkeys with EHV-1 of horse origin-A Study. J. Equine Sci., 11(2):29-33.

8. Abdelgawad, A.; Damiani, A.; Ho, S.Y.W.; Strauss, G.; Szentiks, C.A.; East, M.L.; Osterrieder, N. and Greenwood, A.D. (2016)
Zebra Alphaherpesviruses (EHV-1 and EHV9): Genetic Diversity, Latency and CoInfections. Viruses, 262(8):1-13.

9. Lara, M.C.S.H.; Villalobos, E.M.C.; Cunha, E.M.S.; Oliveira, J.V.; Castro, V.; Nassar, A. F.C. (2017). Occurance of viral diseases in donkeys (Equusasinus) in Sao Paulo State, Brazil. Braz. J. Vet. Res. Anim. Sci., 54(2): 154-158.

10. Kleiboeker, S.B.; Schommer. S.K.; Johnson, P.J.; Ehlers, B.; Turnquist, S.E.; Boucher, M. and Kreeger, J.M. (2002). Association of two newly recognized herpesviruses with interstitial pneumonia in donkeys (Equusasinus). J. Vet. Diagn. Invest., 14:273280.

11. LeCuyer, T.E.; Rink, A.; Bradway, D.S.; Evermann, J.F.; Nicola, AV.; Baszler, T. and Haldorson, G.J. (2015). Abortion in a Mediterranean miniature donkey (Equusasinus) associated with a gamma herpesvirus similar to Equidherpesvirus 7. J. Vet. Diagn. Invest., 27(6):749-753.

12. Van Maanen, C. (2003). Equine herpesvirus 1 and 4 infections: An update. Vet. Quarterly, 24(2):57-78.

13. Smiley, J.R. (2004). Herpes simplex virus virion host shutoff protein: immune evasion mediated by a viral Rnase?. J. Virol., 78(3): 1063-1068.

14. Fuentealba, N.A.; Zanuzzi, C.N.; Scrochi, M.R.; Sguazza, G.H.; Bravi, M.E. (2014). Protective effects of intranasal immunization with recombinant glycoprotein $\mathrm{D}$ in pregnant $\mathrm{BALB} / \mathrm{c}$ mice challenged with different strains of equine herpesvirus 1. J. Compar. Pathol., 151(4):384-393.

15. Liu, S.A.; Stanfield, B.A.; Chouljenko, V.N.; Naidu, S.; Langohr, I.; Piero, F.D.; Ferracone, J.; Roy, A.A. and Kousoulas, G.K. (2017). Intramuscular immunization of mice with live-attenuated herpes simplex virus 1 vaccine strain $\mathrm{VC} 2$ expressing equine herpesvirus 1 (EHV-1) Glycoprotein D generates Anti-EHV-1 immune response in mice. J. Virol., 91(12):21-35.

16. Gosztonyi, G.; Borchers, K. and Ludwig, H.; (2009). Pathogenesis of equine herpesvirus-1 infection in the mouse model. Acta. Pathol. Microbial. Immunol. Scandinavica, (APMIS) 117(1):10-21. 
17. EÖry, M.L.; Zanuzzi, C.N.; Fuentealba, N.A.; Sguazza, G.H.; Gimeno, E.J.; Galosi, C.M. and Barbeito, C.G. (2013). Effect of different anesthetics in the murine model of EHV-1 infection. Vet. Pathol., 50(5):844856.

18. Taktaz, H.T.; Nekoei, S.; Vazirian, B.; Doosti, A.; Khamesipour, F. and Anyanwu, M.U. (2015). Molecular detection of equine herpesvirus type 1 and 4 infection in healthy horses in Isfahan Central and Shahrekord Southwest regions, Iran. Bio. Med. Res. Int., (Article ID 917854). 7 pages. http://doi.org/10.1155/2015/917854.

19. Carvalho, R.; Passos, L.M.F.; Oliveira, A.M.; Henry, M. and Martins, A.S. (2000). Detection of equine herpesvirus 1 DNA in a single embryo and horse semen by polymerase chain reaction. Arq. Bras. Vet. Zootec., 52(4). Online version.

20. Allen, G.P. and Breathnach, C.C. (2006). Quantitation by real-time PCR of the magnitude and duration of leucocyteassociated viraemia in horses infected with neuropathogenic vs. non neuropathogenic strains of EHV-1. Equine Vet. J., 38(3):252257.

21. Perkins, G.A.; Goodman, L.B.; Dubovi, E.J.; Kim, S.G. and Osterrieder, N. (2008). Detection of equine herpesvirus-1 in nasal swabs of horses by quantitative Real-Time PCR. J. Vet. Intern. Med., 22:1234-1238.

22. Zhang, Y.; Charvat, R.A.; Kim, S.K. and O'Callaghan, D.J. (2014). The EHV-1 UL4 protein that tempers viral gene expression interacts with cellular transcription factors. Virol., 449: 25-34.

23. Azmi, M. and Field, H.J. (1993). Cellmediated antiviral response to equine herpesvirus 1 demonstrated in a murine infection model by means of adoptive transfer of immune cells. J. General Virol., 74:275-280.

24. Platt, R.; Sponseler, B.A.; Chiang, Y. and Roth, J.A. (2010). Cell mediated immunity evaluation in foals infected with virulent herpesvirus-1 by multi-parameter flow cytometry. Vet. Immunol. Immunopathol., 135(3-4):275-281.

25. Azmi, M. and Field, H.J. (1993). Interactions between equine herpesvirus type 1 and equine herpesvirus type 4: $\mathrm{T}$ cell responses in a murine infection model. J. General Virol., 74:2339-2345.

26. Goerhring, L.S.; Landolt, G.A. and Morley, P.S. (2010). Detection and management of an outbreak of equine herpesvirus type 1 infection and associated neurological disease in a veterinary teaching hospital. J. Vet. Int. Med., 24(5):1176-1183.

27. Varrasso, A.; Dynon, K.; Ficorilli, N.; Hartley, C.A.; Studdert, M.J. and Drummer, H.E. (2001). Identification of equine herpesvirus 1 and 4 by polymerase chain reaction. Aust. Vet. J. 79:563-569.

28. Diallo, I.S.; Hewitson, G.; Wright, L.; Rodwell, B.J. and Corney, B.G. (2006). Detection of equine herpesvirus 1 using a real-time polymerase chain reaction. J. Virol. Methods, 131:92-98.

29. Allen, G.P. (2007). Development of a real time polymerase chain reaction assay for rapid diagnosis of neuropathogenic strains of equine herpesvirus-1. J.Vet. Diagnos. Invest., 19:69-72.

30. Diallo, I.S.; Hewitson, G.; Wright, L.; Kelly, M.A.; Rodwell, B.J. and Corney, B.G. (2007). Multiplex real-time PCR for detection and differentiation of equidherpesvirus 1 (EHV-1) and equid herpesvirus-4 (EHV-4). Vet. Microbiol., 123:93-104. 


\section{الكشف الجزيئي عن فيروس هريز الخيول نمط 1 في الخيول والحمير المحلية

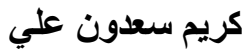 \\ فرع الاحياء المجرية، كلية الطب البيطري، جامعة ديالى، العراق.}

E-mail: alajeelikarim@gmail.com

\section{الخلاصة}

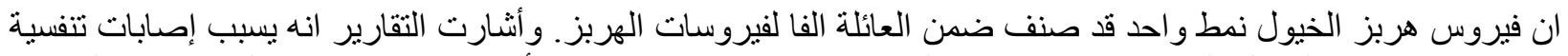

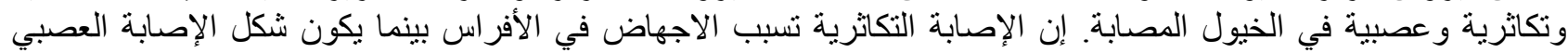

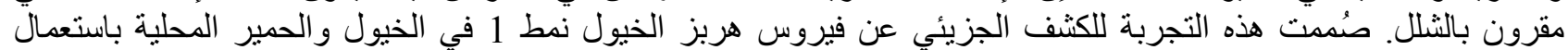
اختبار تفاعل سلسلة انزيم البلمرة. حيث جُمعت 25 نموذج من خلايا الدم البيضاء من الخيول الخيول المحلية (Equus feruscaballus)

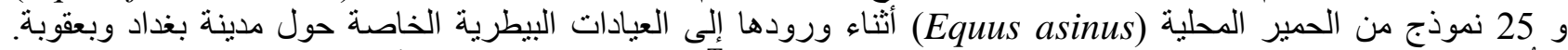
إستُخلص الـDNA من النماذج باستعمال عدة الإستخلاص من شركة

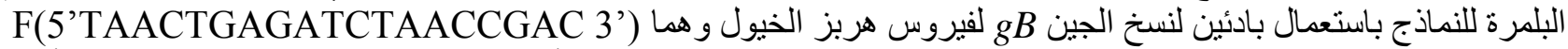

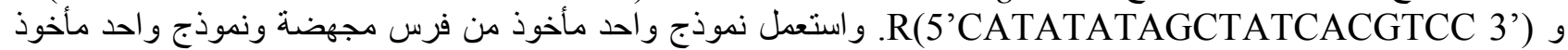

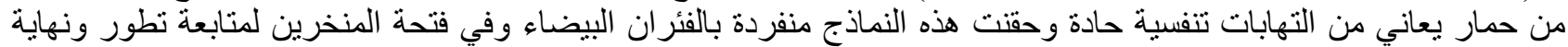

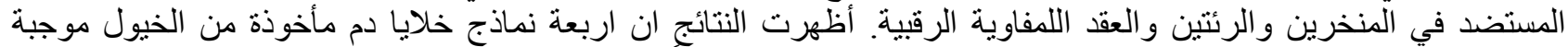

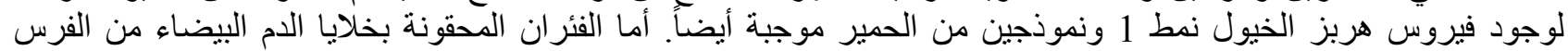

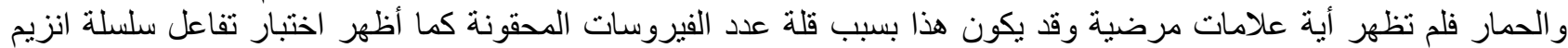

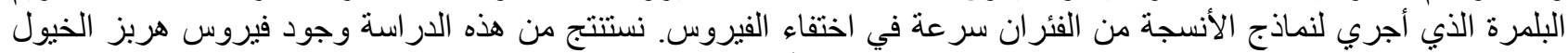

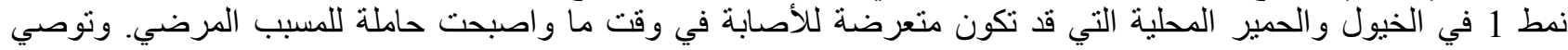

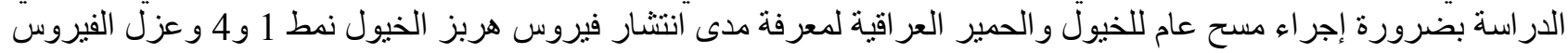
الكلمات المفتاحية: فيروس هربز الخيول، الخيول العربية المحلية، الحمير المحلية، الفئران، تفاعل سلسلة انزيم البلمرة. 